\title{
A review of the abuse potential assessment of atomoxetine: a nonstimulant medication for attention-deficit/hyperactivity disorder
}

\author{
Himanshu P. Upadhyaya • Durisala Desaiah • Kory J. Schuh • Frank P. Bymaster • \\ Mary J. Kallman • David O. Clarke • Todd M. Durell • Paula T. Trzepacz • \\ David O. Calligaro • Eric S. Nisenbaum • Paul J. Emmerson • Leslie M. Schuh • \\ Warren K. Bickel • Albert J. Allen
}

Received: 15 March 2012 / Accepted: 12 January 2013 / Published online: 9 February 2013

(C) The Author(s) 2013. This article is published with open access at Springerlink.com

\begin{abstract}
Rationale Treatment of attention-deficit/hyperactivity disorder (ADHD) has for many years relied on psychostimulants, particularly various formulations of amphetamines and methylphenidate. These are central nervous system stimulants and are scheduled because of their abuse potential. Atomoxetine (atomoxetine hydrochloride; Strattera ${ }^{\circledR}$ ) was approved in 2002 for treatment of ADHD, and was the first nonstimulant medication approved for this disorder. It was
\end{abstract}

H. P. Upadhyaya $(\varangle) \cdot$ D. Desaiah $\cdot$ K. J. Schuh $\cdot$ D. O. Clarke •

T. M. Durell • P. T. Trzepacz • D. O. Calligaro • E. S. Nisenbaum •

P. J. Emmerson • A. J. Allen

Eli Lilly and Company, Indianapolis, IN 46285, USA

e-mail: upadhyayahp@lilly.com

H. P. Upadhyaya

Department of Psychiatry and Behavioral Sciences, Medical

University of South Carolina, Charleston, SC, USA

\section{F. P. Bymaster}

Department of Psychiatry, Indiana University School of Medicine, Indianapolis, IN, USA

\section{J. Kallman}

Covance Laboratories, Greenfield, IN, USA

L. M. Schuh

St. Vincent Carmel Hospital Bariatric Center for Excellence,

Carmel, IN, USA

W. K. Bickel

Virginia Tech Carilion Research Institute, Roanoke, VA, USA

H. P. Upadhyaya

The University of Texas Medical School at Houston, Houston, TX, USA classified as an unscheduled medication indicating a low potential for abuse. However, the abuse potential of atomoxetine has not been reviewed.

Objectives In this article, we review the evidence regarding abuse potential of atomoxetine, a selective inhibitor of the presynaptic norepinephrine transporter, which is unscheduled/unrestricted in all countries where it is approved.

Methods Results from receptor binding, in vitro electrophysiology, in vivo microdialysis, preclinical behavioral, and human laboratory studies have been reviewed.

Results Atomoxetine has no appreciable affinity for, or action at, central receptors through which drugs of abuse typically act, i.e., dopamine transporters, $\mathrm{GABA}_{\mathrm{A}}$ receptors, and opioid $\mu$ receptors. In behavioral experiments in rodents, atomoxetine does not increase locomotor activity, and in drug discrimination studies, its profile is similar to that of drugs without abuse potential. Atomoxetine does not serve as a reinforcer in monkey self-administration studies, and human laboratory studies suggest that atomoxetine does not induce subjective effects indicative of abuse.

Conclusion Neurochemical, preclinical, and early clinical studies predicted and supported a lack of abuse potential of atomoxetine, which is consistent with the clinical trial and postmarketing spontaneous event data in the past 10 years.

Keywords Atomoxetine $\left(\right.$ Strattera $\left.{ }^{\circledR}\right) \cdot$ ADHD $\cdot$ Abuse potential $\cdot$ Nonstimulant

\section{Introduction}

Attention-deficit/hyperactivity disorder (ADHD) (APA 2000) is an early onset childhood disorder that is estimated to occur in $3 \%$ to $9 \%$ of children and adolescents in the 
USA (Faraone et al. 2003; Greydanus et al. 2007) and $4 \%$ to $8 \%$ worldwide (Kessler et al. 2006; Smoot et al. 2007). Frequently associated with impaired academic and social functioning, ADHD persists into adulthood in $50 \%$ to $70 \%$ of affected youth (Barkley et al. 2002; Hechtman 2000). For decades, management of ADHD relied primarily on psychostimulants, such as amphetamines and methylphenidate, for which short- and long-acting formulations are available through a wide variety of branded and generic manufacturers. Although their efficacy is well documented, psychostimulants are controlled substances because of their documented abuse potentials. Amphetamines and methylphenidate are currently classified as schedule II drugs by the US Controlled Substance Act (CSA), indicating that while they have an approved medical use, they also have significant abuse liabilities, which raises concerns about nonmedical use in patients with ADHD, including misuse, abuse, or diversion to individuals without ADHD (Substance Abuse and Mental Health Services Administration 2006; The National Center on Addiction and Substance Abuse at Columbia University 2007). A wide range of drug classes are subject to regulation under the CSA including central nervous system depressants and stimulants. CSA requires an eight-factor analysis for all scheduling decisions by the Drug Enforcement Administration (http://www.fda.gov/ downloads/AboutFD A/Centers Offices/CDER/ UCM180870.pdf). This analysis includes factors such as its actual or relative potential for abuse; pharmacological effect; other current scientific knowledge; history and current pattern of abuse; scope, duration, and significance of abuse; public health risk; psychic or physiological dependence potential; and if the drug is an immediate precursor of a controlled substance under section 21 USC 811(c). Scheduling of a drug regulated under CSA can influence prescribing, utilization, and manufacturing requirements of that drug.

Atomoxetine is a selective inhibitor of the presynaptic norepinephrine (NE) transporter, with minimal affinity for noradrenergic receptors or other neurotransmitter transporters or receptors (Bymaster et al. 2002). In 2002, it was approved by the US Food and Drug Administration (FDA) as an uncontrolled, nonstimulant treatment for pediatric, adolescent, and adult ADHD (Michelson et al. 2002, 2003; Spencer et al. 1998, 2002). Atomoxetine has been shown to be efficacious for the treatment of ADHD with a favorable safety profile (Simpson and Plosker 2004; Garnock-Jones and Keating 2010).

Recently, extended release formulations of two nonstimulant $\alpha(2 \mathrm{~A})$-adrenoceptor agonists guanfacine and clonidine, have been approved in the USA for the treatment of ADHD in children and adolescents. Like atomoxetine, both guanfacine and clonidine have not been scheduled as controlled substances (http://pi.shirecontent.com/PI/PDFs/ Intuniv_USA_ENG.pdf; http://www.accessdata.fda.gov/ drugsatfda_docs/label/2009/017407s034lbl.pdf).
In addition to concerns regarding diversion of prescribed medications, treatment of patients with ADHD, especially adolescents and adults, is complicated by their high comorbidity for substance use disorders (Biederman et al. 1997; Molina and Pelham 2003; Shekim et al. 1990; Upadhyaya et al. 2005; Wilens et al. 1997). Its effect on neurobiological pathways suggests that atomoxetine has less abuse potential than stimulants (Wee and Woolverton 2004) due to its lack of increase of dopamine (DA) transmission in the mesolimbic and mesocortical pathways up to the nucleus accumbens (NAc) (Bymaster et al. 2002; Simpson and Plosker 2004). Previous reviews have demonstrated that atomoxetine is useful for patients at risk of substance abuse or who do not wish to take a controlled substance: atomoxetine is effective, has a favorable safety profile, and has a negligible risk of abuse or misuse (Garnock-Jones and Keating 2010; Simpson and Plosker 2004). However, a comprehensive review of abuse potential assessments of atomoxetine compared with psychostimulant drugs has not been published. In this review article, we review previously published literature on abuse potential testing for atomoxetine and present research findings that demonstrate the low abuse potential of atomoxetine in contrast to psychostimulant medications, such as amphetamine and methylphenidate.

\section{Neurobiology of stimulant action}

The mesolimbic and mesocortical pathways, both part of the brain reward circuitries, connect the structures that are thought to control and regulate stimulant activity and behavior. The mesolimbic system extends from the ventral tegmental area via the medial forebrain bundle to the NAc, which is the primary release site for DA (Koob 1992).

Amphetamines and methylphenidate have similar effects on DA and NE neurotransmission (Kahlig et al. 2005; Simpson and Plosker 2004). Both substances primarily increase DA and, to a lesser degree, noradrenergic activity in neural systems. Both block presynaptic reuptake of DA, resulting in higher synaptic levels, as suggested by microdialysis studies (Bredeloux et al. 2007; Bymaster et al. 2002; Koda et al. 2010; Mazei et al. 2002; Pontieri et al. 1995). Amphetamine also causes nonvesicular release of DA through the dopamine transporter (DAT) by promoting the exchange for cytosolic DA (Partilla et al. 2006; Sandoval et al. 2002). Amphetamine causes DAT-mediated DA efflux by two independent mechanisms: (1) a slow process consistent with an exchange mechanism and (2) a process that results in rapid (milliseconds) bursts of DA efflux that is comparable to transport through a channel such as DAT. This rapid release of large numbers of DA molecules plays a role in the synaptic actions and psychostimulant effects of amphetamine and related compounds (Kahlig et al. 2005). 
Therapeutic doses of oral methylphenidate can effectively block DATs (Volkow et al. 1998) and significantly increase extracellular DA (Volkow et al. 2001) in humans. An evaluation of the levels of DAT blockade is important in light of the evidence that DATs are involved in mediating the reinforcing effects of cocaine (Ritz et al. 1987). Volkow et al. (1997) demonstrated that the extent and time course of DAT occupancy in human volunteers who abuse cocaine correlated with the "high" subjective effect of cocaine. A review of its clinical use and abuse indicated that reinforcing effects of methylphenidate may be attributed to large and rapid increases in extracellular DA, whereas therapeutic effects occur when the drug elicits slow, steady-state DA increase (Volkow and Swanson 2003).

Evidence for abuse potential of stimulants

Prevalence rates Comprehensive reviews on this subject are provided in the publications by Kollins (2007) and Wilens et al. (2008a). In 2005, the Drug Abuse Warning Network (Substance Abuse and Mental Health Services Administration 2007) estimated that stimulants, including amphetamines, were involved in 138,950 emergency department visits; the rates were highest among patients 18 to 44 years old. Further, the annual prevalence rate for amphetamine use among US 12th graders was reported to be $8.2 \%$ in 2011 (Johnston et al. 2012). The trend of amphetamine use among college students has increased from $4.2 \%$ in 1996 to $9.0 \%$ in 2010 (Johnston et al. 2009, 2011). Further, the annual prevalence rates for methylphenidate use in 8 th, 10 th, and 12 th graders was reported to be $1.6 \%, 2.9 \%$, and $3.4 \%$, respectively (Johnston et al. 2008). While among college-aged students, the prevalence of illicit methylphenidate use was $4.2 \%$ in 2005 (Johnston et al. 2009).

A study based on Internet-based epidemiological survey evaluated the prevalence of nonmedical use of prescription medications for ADHD (Novak et al. 2007). This study reported that $\sim 7.01 \%$ of US adults aged 18-49 years used a stimulant ADHD medication for nonmedical purpose at least once in their lifetime. The prevalence of nonmedical use was more for short-acting stimulants versus long-acting ones. Although the original study reported productivity as the most frequent reason for nonmedical use of ADHD medication (Novak et al. 2007), a post hoc analysis revealed that a substantial proportion of young adults may be using stimulants for self-medication of ADHD symptoms (Upadhyaya et al. 2010). The motivation for nonmedical use of immediate- and extended-release formulations of stimulants may be distinct, such as recreational versus productivity. Irrespective of the intended nonmedical use, friends and family remain an important source for diverted medication (Novak et al. 2007; Upadhyaya et al. 2010).
Adverse effects Adverse events related to various forms of amphetamines include abuse, dependence, and neurotoxicity. Evidence indicates that the adverse effects observed in humans and experimental animals can be explained by the critical role of amphetamines on DA and NE. These include arousal, hyperactivity, stereotypic perseverative movements, psychomotor depression, cognitive impairment, hallucinatory-like behaviors, and chronic self-administration (Berman et al. 2009). Chronic administration has also shown neurotoxicity that can persist for years, such as deficits in phenotypic markers for dopaminergic nerve terminals, enlarged chromatolytic medulla neurons in cats, and swollen or reduced dopaminergic axons, and serotonin deficits in rodents (Berman et al. 2009).

Self-administration, reinforcing, and subjective effects Human abuse potential has been well predicted through the animal self-administration model paradigms. Methylphenidate was self-administered by nonhuman primates (Bergman et al. 1989; Johanson and Schuster 1975; Wilson et al. 1971) and humans (Jasinski et al. 2008). In a human laboratory study (Jasinski et al. 2008), methylphenidate produced significant positive effects and drug-liking. Both intranasal (Garland 1998; Massello and Carpenter 1999) and intravenous (Parran and Jasinski 1991) use of methylphenidate have also been reported. This is further confirmed by the results of a placebo-controlled human laboratory study that examined the reinforcing and subjective effects of methylphenidate and D-amphetamine in non-drug-abusing subjects (Rush et al. 2001). It was demonstrated that methylphenidate and D-amphetamine could function as reinforcers and produce stimulant-like subjective effects, leading to abuse potential. Both drugs produced comparable subject-rated drug effects, including increased A scores on the Addiction Research Center Inventory (ARCI), increased ratings of "any effect" and "like drug" on the subject-rated drug-effect questionnaire. Although, in this study the reinforcing and subject-rated drug effects with methylphenidate were observed only at the highest dose tested $(40 \mathrm{mg})$, this did not undermine its drug abuse potential. Thus, the existing evidence, including surveys and controlled laboratory conditions, indicates that amphetamines and methylphenidate have significant abuse potential.

Atomoxetine: lack of evidence for abuse potential

Various biochemical, pharmacological (e.g., receptor binding, in vivo microdialysis), and behavioral studies in animals, and human studies that measured the subjective effects of atomoxetine have been conducted to assess its potential for abuse potential. Stimulant-induced increases in extracellular DA levels, especially in the NAc, plays an 
important role in their drug abuse potential, and therefore, atomoxetine was examined for its effect on extracellular levels in the NAc as well as various neuronal receptor activities. The methods and results of these studies are described in the following sections.

\section{Receptor binding studies}

Receptor-binding studies may be used to determine the binding affinity of an active substance to known targets involved in drug dependence (e.g., opioid receptors, 5-HT, and dopamine transporters and receptors, NMDA, GABA, nicotinic acetylcholine, and cannabinoid receptors). The agonist or antagonist effects of binding to a receptor can be determined by functional assays at the cellular level. Studies assessing the affinity and functional effects of atomoxetine on target receptors are presented below.

The inhibition constant $\left(K_{\mathrm{i}}\right.$ values, lower values indicate greater affinity) of atomoxetine for binding of ligands to monoamine uptake transporters (Bymaster et al. 2002) was $K_{\mathrm{i}}=5.4 \mathrm{nM}$ for the human NE transporter, $K_{\mathrm{i}}=87 \mathrm{nM}$ for human serotonin (5-HT; see section "In vivo animal studies"), and $K_{\mathrm{i}}=1451 \mathrm{nM}$ for DATs. Atomoxetine also has a low affinity for a number of other binding sites, suggesting selectivity for the NE transporter. In contrast, methylphenidate has higher affinity for the human DA transporter $\left(K_{\mathrm{i}}=34 \mathrm{nM}\right)$ than for the NE transporter $\left(K_{\mathrm{i}}=339 \mathrm{nM}\right)$. The binding affinities of atomoxetine and other agents for the DA and NE transporter, compiled from several publications, are provided in Table 1 . The ratio of $K_{\mathrm{i}}$ values for DA and NE transporters reveals that several nonscheduled drugs, including atomoxetine, have much higher ratio values compared with scheduled stimulants (methylphenidate, D-amphetamine, and cocaine), whose ratios are less than 1.0. In contrast, the ratio for atomoxetine is 342 , indicating much higher affinity for the NE than DA transporter and therefore suggesting a lower potential for DA-mediated substance abuse.

In addition, the binding affinity and functional activity of atomoxetine and its major metabolite, 4-hydroxyatomoxetine, was assessed at 63 neuronal receptors and binding sites, including neurotransmitter receptor sites such as the opioid $\mu$ receptor, second messengers, ion channels, transporters, and brain and gut peptides (Bymaster et al. 2002). Atomoxetine at $1 \mu \mathrm{M}$ did not inhibit any of these receptors by more than $50 \%$, except binding to opioid $\sigma_{1}$ receptor, which was inhibited by $51.4 \%$. The 4-hydroxyatomoxetine metabolite $(1 \mu \mathrm{M})$ inhibited radioligand binding to opioid $\delta_{1}, \kappa_{1}$, and $\mu$ receptors by $52 \%, 59 \%$, and $66 \%$, respectively. In a separate experiment, 4-hydroxyatomoxetine was found to have relatively low affinity for these same three receptors, with $K_{\mathrm{i}}$ values of $300 \mathrm{nM}, 95 \mathrm{nM}$, and $422 \mathrm{nM}$, respectively (Bymaster et al. 2002).

\section{Electrophysiological studies}

Drugs with abuse potential include sedative/hypnotic drugs, whose mechanism of action are thought to involve the agonistic action on $\gamma$-aminobutyric acid $\left(\mathrm{GABA}_{\mathrm{A}}\right)$ receptors (Bergman et al. 2000). Although atomoxetine had low affinity for $\mathrm{GABA}_{\mathrm{A}}$ and benzodiazepine receptors in binding studies (Bymaster et al. 2002), the potential actions of atomoxetine on $\mathrm{GABA}_{\mathrm{A}}$ receptors were further evaluated using electrophysiological recording of $\mathrm{GABA}_{\mathrm{A}}$ receptordependent activity of ventrobasal thalamic relay neurons in a rat brain slice preparation (Zhang et al. 1997).

The possibility that atomoxetine $(10 \mu \mathrm{M})$ might act as an agonist, antagonist, or allosteric modulator of $\mathrm{GABA}_{\mathrm{A}}$ receptors was assessed by recording changes in either the resting membrane potential of ventrobasal neurons associated with $\mathrm{GABA}_{\mathrm{A}}$ receptor activity or the inhibitory postsynaptic potentials (IPSPs) evoked by electrical stimulation of the GABAergic inputs from the ventrobasal neurons of the reticular thalamic nucleus (Zhang et al. 1997). Possible direct agonist actions of atomoxetine $(1$ and $10 \mu \mathrm{M})$ were evaluated by measuring changes in the resting membrane potential of neurons before and during compound application. In these experiments, selected concentrations of the $\mathrm{GABA}_{\mathrm{A}}$ receptor agonist muscimol $(1 \mu \mathrm{M})$, the $\mathrm{GABA}_{\mathrm{A}}$ receptor antagonist bicuculline methochloride $(10 \mu \mathrm{M})$, and the $\mathrm{GABA}_{\mathrm{A}}$ receptor allosteric modulator pentobarbital $(10 \mu \mathrm{M})$ were used as positive controls for agonist, antagonist, and potentiator activity, respectively (Zhang et al. 1997).

Identical experiments were performed using nisoxetine hydrochloride $(1 \mu \mathrm{M}$ and $10 \mu \mathrm{M})$, another selective NE transporter inhibitor, which is widely used in scientific research as a standard selective NE reuptake inhibitor (Graham and Langer 1992). Results showed that atomoxetine (concentrations up to $10 \mu \mathrm{M}$ ) did not alter the IPSPs in ventrobasal neurons evoked by electrical stimulation of the slice preparation (Fig. 1a). However, in the same neurons, pentobarbital $(10 \mu \mathrm{M})$ enhanced and bicuculline methochloride $(10 \mu \mathrm{M})$ blocked $\mathrm{GABA}_{\mathrm{A}}$ receptor-dependent IPSPs. Atomoxetine $(1 \mu \mathrm{M})$ also did not affect the membrane potential of ventrobasal neurons, whereas muscimol $(1 \mu \mathrm{M})$ hyperpolarized and bicuculline methochloride $(10 \mu \mathrm{M})$ blocked the hyperpolarization in these same neurons (Fig. 1b). In addition, nisoxetine $(1 \mu \mathrm{M}$ and $10 \mu \mathrm{M}$ ) did not affect the membrane potential or IPSPs evoked in ventrobasal neurons (data not shown). Collectively, these data are consistent with in vitro binding studies and indicate that atomoxetine does not have agonist, antagonist, or positive allosteric actions at $\mathrm{GABA}_{\mathrm{A}}$ receptors.

\section{In vivo animal studies}

Rat neurotransmitter studies Bymaster et al. (2002) examined atomoxetine's ability to block neurotransmitter 
Table 1 Binding affinity of atomoxetine, other norepinephrine transporter inhibitors, and psychostimulants for the norepinephrine and dopamine transporters compiled from several publications

\begin{tabular}{|c|c|c|c|}
\hline \multirow[t]{2}{*}{ Compound } & \multicolumn{2}{|l|}{$K_{\mathrm{i}}(\mathrm{nM})$, mean } & \multirow[t]{2}{*}{ Ratio DAT/NET } \\
\hline & NET & DAT & \\
\hline \multicolumn{4}{|l|}{ Unscheduled } \\
\hline Atomoxetine & $3.7\left(5.4,{ }^{\mathrm{a}} 2.0^{\mathrm{b}}\right)$ & $1,266\left(1,451,{ }^{\mathrm{a}} 1,080^{\mathrm{b}}\right)$ & 342 \\
\hline Desipramine & $2.4\left(3.8,{ }^{\mathrm{a}} 3.5,{ }^{\mathrm{c}} 1.6,{ }^{\mathrm{d}} 0.8^{\mathrm{b}}\right)$ & $>2,295\left(>10,000,{ }^{\mathrm{a}} 1,400,{ }^{\mathrm{c}} 3,190^{\mathrm{b}}\right)$ & $>956$ \\
\hline \multicolumn{4}{|l|}{ Scheduled } \\
\hline Methylphenidate & $427\left(339,{ }^{\mathrm{a}} 514^{\mathrm{c}}\right)$ & $46\left(34,{ }^{\mathrm{a}} 84,{ }^{\mathrm{c}} 21^{\mathrm{e}}\right)$ & 0.11 \\
\hline d-Amphetamine & $257^{\mathrm{d}}$ & $190^{\mathrm{e}}$ & 0.74 \\
\hline Cocaine & $2,100^{\mathrm{c}}$ & $180\left(120,{ }^{\mathrm{c}} 240^{\mathrm{e}}\right)$ & 0.09 \\
\hline
\end{tabular}

Abbreviations: $D A T=$ dopamine transporter; $N E T=$ norepinephrine transporter

${ }^{\text {a }}$ Bymaster et al. (2002)

b Tatsumi et al. (1997)

${ }^{\mathrm{c}}$ Gatley et al. (1996)

${ }^{\mathrm{d}}$ Cheetham et al. (1996)

${ }^{\text {e }}$ Pristupa et al. (1994)

depletion in a rat brain induced by monoamine transporterdependent neurotoxins. After rats were injected with the 5-HT selective neurotoxin $\mathrm{p}$-chloramphetamine hydrochloride (p-CA), whole brain 5-HT concentrations were measured using high-pressure liquid chromatography with electrochemical detection (HPLC-EC). Results showed that atomoxetine did not block depletion of rat brain 5-HT produced by p-CA, indicating that atomoxetine does not significantly block 5-HT transporters in vivo. To measure the ability of atomoxetine to block NE uptake, the NE transporter-requiring neurotoxin $N$-(2-chloroethyl)- $N$-ethyl-2-bromobenzylamine hydrochloride (DSP-4) was injected. Cortical NE concentrations were measured $6 \mathrm{~h}$ after injection and analyzed using HPLC-EC.
Atomoxetine dose-dependently and potently blocked depletion of NE in the rat hypothalamus by DSP-4, demonstrating blockade of NE transporters in vivo.

In vivo microdialysis is an important technique, which helps in the elucidation of the neurochemical profile, mechanism of action, and effects of several drugs on neurotransmitter systems. This technique is used to measure druginduced changes in concentrations of neurotransmitters such as acetylcholine, glutamate, GABA, and monoamines, and their respective metabolites in the extracellular fluid in discrete brain regions (Darvesh et al. 2011). In vivo microdialysis studies in conscious rats (Bymaster et al. 2002) showed that extracellular concentrations of NE in the
Fig. 1 Atomoxetine does not affect a GABA-ergic IPSPs or $\mathbf{b}$ the resting membrane potential of ventrobasal thalamic neurons in rat brain slices. Data points reflect percentage of control in $\mathbf{a}$ and mean $\pm \mathrm{SD}$ in $\mathbf{b}$.

* Significant difference from control at $p \leq 0.05$.

Abbreviations: $\mathrm{AUC}=$ area under the curve; GABA $=\gamma$ aminobutyric acid $(G A B A)$; IPSP $=$ inhibitory postsynaptic potential $(I P S P) ; \mathrm{SD}=$ standard deviation

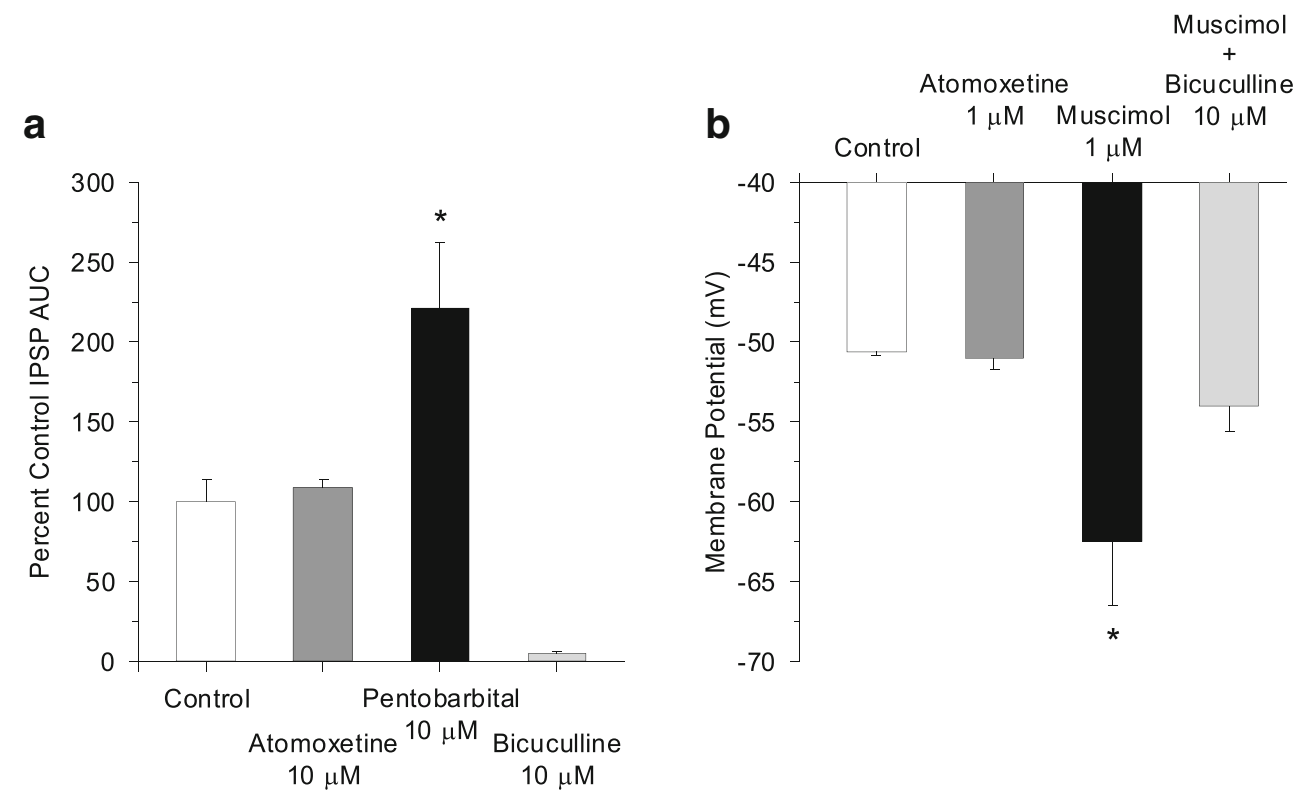


Table 2 Summary of abuse potential parameters for atomoxetine compared with stimulants, methylphenidate and amphetamine

\begin{tabular}{cccc}
\hline & Atomoxetine & Methylphenidate & Amphetamine \\
\hline $\begin{array}{c}\text { Animal studies } \\
\text { In vivo } \\
\text { microdialy } \\
\text { sis studies }\end{array}$ & $\begin{array}{c}\text { Did not increase extracellular DA } \\
\text { in the DA-rich NAc or striatum }\end{array}$ & $\begin{array}{c}\text { a } \\
\text { Increased extracelluar DA } \\
\text { in the NAc }\end{array}$ & $\begin{array}{c}\text { Increased extracelluar DA in } \\
\text { specific regions of the brain }\end{array}$ \\
$\begin{array}{c}\text { administrative } \\
\text { behaviour }\end{array}$ & No self administration observed & $\begin{array}{c}\text { Doses greater than } 0.03 \mathrm{mg} / \mathrm{Kg} \\
\text { produced self-administration }\end{array}$ & $\begin{array}{c}\text { Doses greater than 0.03 mg/Kg } \\
\text { produced self-administration }\end{array}$ \\
$\begin{array}{c}\text { Human studies } \\
\begin{array}{c}\text { Subjective- } \\
\text { drug effects }\end{array}\end{array}$ & $\begin{array}{c}\text { 90-mg dose increased "bad" and "sick" portions of VAS, } \\
\text { and LSD subscale on ARCI; not observed with lower } \\
\text { doses (20 mg and 45 mg) }\end{array}$ & $\begin{array}{c}\text { 40-mg dose increased } \\
\text { stimulant portions of VAS } \\
\text { and ARS, and }\end{array}$ & - \\
$\begin{array}{c}\text { Discriminative } \\
\text { stimulus }\end{array}$ & $\begin{array}{c}\text { Partially substituted for methylphenidate (33 \%-50 \%); } \\
\text { stimulant-like drug effects were lower compared to } \\
\text { stimulants (methylphenidate and D-amphetamine) }\end{array}$ & $\begin{array}{c}\text { Increased drug-appropriate } \\
\text { responding and produced } \\
\text { stimulant-like effects }\end{array}$ & $\begin{array}{c}\text { Increased drug-appropriate } \\
\text { responding and produced } \\
\text { stimulant-like effects }\end{array}$ \\
\hline
\end{tabular}

Abbreviations: $A R C I=$ Addiction Research Center Inventory; $A R S=$ Adjective Rating Scale; $D A=$ dopamine; $L S D=$ lysergic acid diethylamine; $N A c=$ nucleus acumbens; $V A S=$ Visual Analog Scale

${ }^{a}$ Bymaster et al. (2002)

${ }^{\mathrm{b}}$ Jones et al. (2000)

${ }^{\mathrm{c}}$ Gasior et al. (2005)

${ }^{\mathrm{d}}$ Heil et al. (2002)

${ }^{\mathrm{e}}$ Lile et al. (2006)

prefrontal cortex were increased in a dose-dependent fashion by atomoxetine, whereas the extracellular concentrations of 5-HT were not significantly altered by atomoxetine up to $3 \mathrm{mg} / \mathrm{kg}$ (intraperitoneal administration) in the brain regions examined including the prefrontal cortex, NAc, and striatum. Furthermore, atomoxetine increased extracellular concentrations of DA to about the same magnitude as NE in the prefrontal cortex; this was attributed to the finding that DA in the prefrontal cortex is taken up by NE transporters (Di Chiara et al. 1992). Higher doses of atomoxetine produced greater and long-lasting increases in extracellular NE and DA in the prefrontal cortex than lower doses.

However, atomoxetine did not increase extracellular DA in the DA-rich NAc or striatum (Bymaster et al. 2002). In contrast to atomoxetine, methylphenidate increased extracellular DA in the NAc, an activity implicated in the reward and reinforcing aspects of this drug (Table 2) (Kuczenski and Segal 1997, 1999). Similar results with atomoxetine microdialysis studies were found in mice (Koda et al. 2010). The importance of microdialysis studies is underscored in a recent review of nonhuman primate imaging studies that found considerable evidence supporting that drug-induced reinforcing effects, DAT occupancy, and increases of extracellular DA levels were closely related (Murnane and Howell 2011).

The immediate-early gene c-fos and its protein products have been increasingly utilized as markers for neuronal activation (Dragunow and Faull 1989; Morgan and Curran 1990; Robertson et al. 1994). Hence, the expression of the neuronal activity marker Fos after atomoxetine administration was determined in several brain regions (Bymaster et al. 2002). In the atomoxetine studies, immunohistochemical localization of the Fos protein allowed the quantification of activated cells in specific forebrain nuclei following vehicle or atomoxetine administration. Atomoxetine significantly and robustly increased the number of Fos-positive cells in the prefrontal cortex ( $80 \pm 28$ vehicle versus $296 \pm 26$ atomoxetine, $p \leq 0.001$ ), but not in the NAc or the striatum (Bymaster et al. 2002). In contrast, methylphenidate induced Fos expression in the striatum of cats (Lin et al. 1996) and persistent c-fos in the NAc and in the frontal cortex of the immature rat brain (Chase et al. 2005). In another study, methylphenidate increased c-fos expression predominately in the sensorimotor striatum, but not in the NAc (Yano and Steiner 2005).

Thus, both the pattern of increase of DA in only the prefrontal cortex as well as increased Fos expression in the prefrontal cortex, but not in the NAc and striatum, indicates a unique profile for atomoxetine compared with methylphenidate that may be related to atomoxetine's low abuse potential.

Drug discrimination paradigm In drug discrimination models, animals are trained to discriminate effects of a particular drug of abuse. Such models have also been used to indicate how prominent the role of DA reuptake blockade is for the abuse potential of a particular drug (Kleven et al. 1990; Rowlett et al. 2007). A number of drug discrimination studies have been conducted in rats (Terry et al. 1994), 
pigeons (Johanson and Barrett 1993; Sasaki et al. 1995; Zhang and Barrett 1991), and monkeys (Kleven et al. 1990; Spealman 1995; Tidey and Bergman 1998) to evaluate the subjective effects produced by atomoxetine and the results overall suggest that atomoxetine has a low abuse potential. Two discrimination studies in pigeons (Johanson and Barrett 1993; Sasaki et al. 1995) reported the generalization of atomoxetine with cocaine $(1.0$ or $1.7 \mathrm{mg} / \mathrm{kg}$ ) or methamphetamine (1.0 or $1.7 \mathrm{mg} / \mathrm{kg})$. In both of these studies, atomoxetine generalized at some dose but generalization was not dose-responsive and was always accompanied by reductions in response rate or a disruption of performance. Cocaine itself produces full generalization and yet is devoid of effects on response rate at the same doses (Terry et al. 1994). Johanson and Barrett (1993) concluded that dopaminergic as well as noradrenergic systems in the pigeons mediate the discriminative stimulus effects of cocaine, while serotonergic systems do not seem to be involved in this response. It was also concluded that NE and DA reuptake inhibition and 5-HT release mediate the discriminative stimulus effects of methamphetamine (Johanson and Barrett 1993; Sasaki et al. 1995). However, data from pigeons is of questionable value in extrapolating to humans, as the pharmacology in this avian species has been shown to differ from that of rodents and primates. In rats and monkeys, when a very low dose of cocaine is used as a training stimulus, atomoxetine has been seen to occasionally generalize to cocaine (Spealman 1995; Terry et al. 1994), but as the training dose of cocaine was escalated to levels that produce frank psychomotor stimulation, the generalization was lost. Furthermore, the generalization sometimes observed with atomoxetine contrasts with that of abused stimulants. While cocaine produced $100 \%$ effects in the rat drug discrimination model, atomoxetine did not generalize to this extent (Terry et al. 1994). Atomoxetine and nisoxetine (another NE reuptake inhibitor) substituted for cocaine in these rats, suggesting NE involvement in the discriminative stimulus effects of low doses of cocaine. Moreover, the generalization was produced only at doses of atomoxetine that had effects on other aspects of behavior (response rates) that question the validity of data interpretation. It is noteworthy that the doses of atomoxetine and nisoxetine that generalized to cocaine also produced substantial decreases in the response rate to about $20 \%$ of the control. However, other drug discrimination studies using cocaine at $10 \mathrm{mg} / \mathrm{kg}$ as a training dose have shown that the NE reuptake inhibitor desipramine, which has not demonstrated abuse potential, substituted or partially substituted and bupropion fully substituted for cocaine (Nicholson et al. 2009; Paterson et al. 2010). Selective 5-HT reuptake inhibitors did not substitute for cocaine (Paterson et al. 2010; Terry et al. 1994).

In rhesus monkeys trained to discriminate cocaine, atomoxetine did not generalize to cocaine, whereas the indirect DA agonists GBR 12909 (vanoxerine), mazindol, nomifensine, and bupropion, each produced dose-related increases in cocaine-appropriate responding, with complete substitution for cocaine achieved at the highest doses of each drug (Kleven et al. 1990).

Similar results are also seen in squirrel monkeys. Atomoxetine produced some generalization at the lowest training dose of cocaine but this did not hold at higher doses of cocaine (Spealman 1995). Moreover, the pattern of responding for atomoxetine observed in the Spealman (1995) study was identical to the pattern observed for desipramine (which lacks abuse potential) and nisoxetine. Similar to cocaine, methamphetamine increases synaptic DA levels by blocking reuptake; in addition, methamphetamine can diffuse through the neuronal membrane and release cytoplasmic DA. In squirrel monkeys trained to discriminate methamphetamine $(0.3 \mathrm{mg} / \mathrm{kg}, \mathrm{IM})$ from saline, a high dose of atomoxetine $(17.8 \mathrm{mg} / \mathrm{kg}$, IM) produced full substitution in 1 of 3 monkeys, whereas lower doses did not produce such an effect in any of the 3 monkeys (Tidey and Bergman 1998).

In summary, a review of animal drug discrimination studies indicates that atomoxetine will generalize to cocaine or methamphetamine under certain conditions, like NE reuptake inhibitors (e.g., imipramine and desipramine) lacking abuse potential. These antidepressants also generalize to the training drug under the same conditions that suggests the involvement of noradrenergic systems in these discrimination models. In monkeys, atomoxetine did not substitute for cocaine. Generalization to cocaine-like effects seems to occur when a low training dose of cocaine or a high dose of atomoxetine is used for testing, which substantially decreases response rates. The data demonstrating that atomoxetine, under some conditions, can generalize to cocaine does not directly imply abuse potential. Despite its different profiles of neurotransmitter effects in the drug discrimination studies, atomoxetine produces a pattern of effects similar to that of tricyclic antidepressants, drugs that have low abuse potential confirmed during many years of clinical use and availability. The nonclinical literature also documents a common subjective effect profile for abused stimulants that maps onto their abuse and dependence potential in man. In contrast, the nonclinical data in the area has distinguished atomoxetine from that of the abused stimulants, including methylphenidate. It was predicted from this distinction that atomoxetine would be devoid of psychomotor stimulant-like abuse and dependence potential and would therefore not be subject to drug diversion.

Self-administration in monkeys Atomoxetine was tested in two separate animal self-administration models that are predictive of abuse potential in humans. In the first study (Wee and Woolverton 2004), rhesus monkeys were prepared with chronic intravenous catheters and trained to press a lever to receive cocaine injections. Various doses of atomoxetine, 


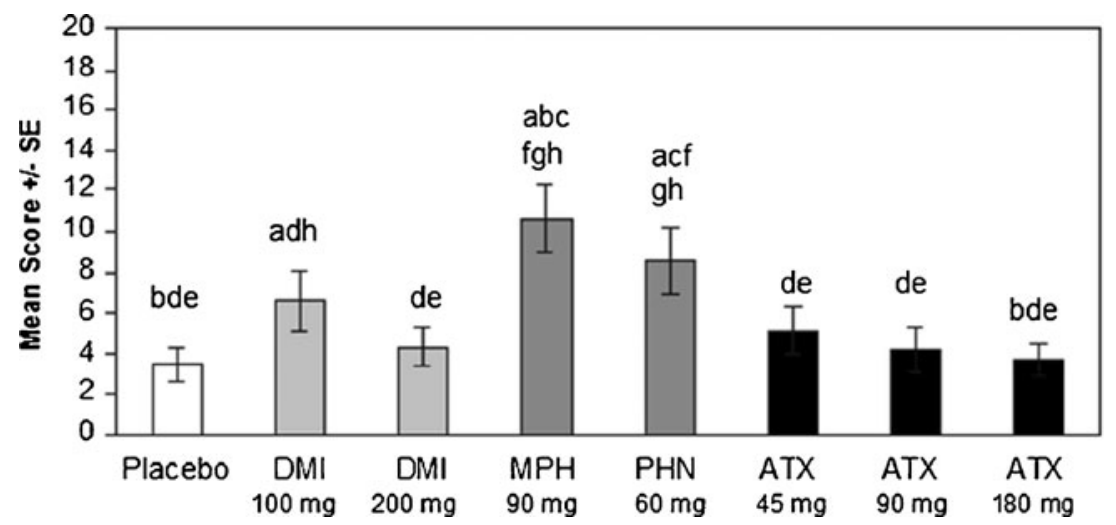

Fig. 2 Effects of placebo, desipramine (100 and $200 \mathrm{mg}$ ), methylphenidate $(90 \mathrm{mg})$, phentermine $(60 \mathrm{mg})$, and atomoxetine $(45,90$, and $180 \mathrm{mg}$ ) on the Drug Rating Questionnaire item "How much do you like the effects you are feeling now?" Six-hour maximum scores (Jasinski et al. 2008). Abbreviations: $A T X=$ atomoxetine; $D M I=$

methylphenidate, desipramine, and their vehicles were periodically substituted for cocaine. A drug dose was considered a positive reinforcer in any monkey if the number of injections it maintained in all test sessions was outside the $95 \%$ confidence interval for all vehicle test sessions. Cocaine and methylphenidate clearly functioned as positive reinforcers, whereas atomoxetine and desipramine did not. The second study employed a choice paradigm (Gasior et al. 2005) in which rhesus monkeys were trained to press one lever for injections of either saline or drug, and another lever for the delivery of food. Dose-effect functions were determined for cocaine, methylphenidate, D-amphetamine, atomoxetine, and desipramine. Saline availability was typically associated with high rates of responding for food. In contrast, availability of cocaine, methylphenidate, or D-amphetamine at doses greater than $0.03 \mathrm{mg} / \mathrm{kg} /$ injection produced $>90 \%$ responding on the injection lever. No dose of atomoxetine or desipramine maintained self-administration behavior on the injection lever until doses were increased to levels that disrupted overall behavioral functioning (Table 2) (Gasior et al. 2005). As such, these results from two different, wellcontrolled nonhuman primate self-administration models suggest that atomoxetine lacks abuse potential.

\section{Human studies}

The results from three abuse potential studies in humans provide valuable evidence to support the low drug abuse potential of atomoxetine compared with other stimulant drugs (summarized in Table 2). In the first study, physiological and subjective effects of atomoxetine and methylphenidate compared with placebo were assessed in a human laboratory study (Heil et al. 2002). Sixteen nondependent, light drug users (average age $=20$ years) participated in six experimental sessions in which they received placebo, atomoxetine $(20,45$, desipramine; $M P H=$ methylphenidate; $P H N=$ phentermine; $S E=$ standard error of the mean. Letters above the bars represent statistical significance: $p<0.05$ vs. a placebo, b DMI $100 \mathrm{mg}$, c DMI $200 \mathrm{mg}$, d MPH 90 mg, e PHN 60 mg, f ATX 45 mg, g ATX 90 mg, h ATX $180 \mathrm{mg}$

$90 \mathrm{mg}$ ) and methylphenidate $(20,40 \mathrm{mg})$ using a doubleblind, Latin square design. Assessments were conducted before drug administration and at 30,60,90,120,150,180, and $240 \mathrm{~min}$ after dosing. In addition to blood pressure (BP) and heart rate (HR), subjective drug effects were measured at each assessment using computer-based versions of Visual Analog Scales (VAS), the ARCI, and Adjective Rating Scales (ARS) (Heil et al. 2002).

The results of this study indicated that relatively few subjective drug effects of atomoxetine were different from the placebo (Heil et al. 2002). Specifically, the highest atomoxetine dose (90 mg) significantly increased the VAS "bad" and "sick" scores. Atomoxetine did not significantly affect scores on any of the ARCI subscales, except for a peak effect on the lysergic acid diethylamide subscale at the $90-\mathrm{mg}$ dose. It could be argued that atomoxetine doses were too low to produce substantial subjective effects. However, doses were sufficiently high to demonstrate significant and to some extent unpleasant physiological effects. In contrast to atomoxetine, methylphenidate increased many self-report measures sensitive to stimulant effects, including the stimulant scales of the ARS, the VAS, and the ARCI benzedrine, amphetamine, and morphine-benzedrine subscales. Because this study of drug effects in humans demonstrated that atomoxetine did not engender pleasurable subjective effects, it provides evidence that atomoxetine is unlikely to have abuse potential.

In the second study, Lile et al. (2006) examined the discriminative stimulus and subjective effects of atomoxetine in six subjects with recent histories of stimulant use. After the subjects acquired the discrimination, they were given test doses of methylphenidate ( 5 to $30 \mathrm{mg}$ ), atomoxetine (15 to $90 \mathrm{mg}$ ), D-amphetamine (2.5 to $15 \mathrm{mg}$ ), triazolam (0.06 to $0.375 \mathrm{mg}$ ), and placebo. Subjective effects questionnaires (ARS, Stimulant-Sensitive Adjective Rating Scale, ARCI, and a locally developed Drug Effect 
Questionnaire [DEQ]), a performance task (Digit-Symbol Substitution Task), and cardiovascular evaluations were also completed. Methylphenidate and D-amphetamine increased drug-appropriate responding and produced stimulant-like subjective effects (e.g., increased ratings of "active/alert/energetic," "stimulated," "shaky," and "jittery") that were significantly different from placebo on all six domains of the DEQ. There was no significant difference between atomoxetine and placebo except for the DEQ domain "any effect" at the 90-mg dose, and for HR and BP effects attributable to noradrenergic activity. Only the 90-mg atomoxetine dose significantly increased methylphenidateappropriate responding relative to placebo. Triazolam produced low, insignificant levels of drug-appropriate responding and sedative-like subjective effects. The authors suggest that the subjective effects profile of atomoxetine, partially overlapping with abused stimulants, and indicative of low abuse potential may mean that atomoxetine could be useful as a replacement therapy for stimulant abuse.

Lastly, in an inpatient study (Jasinski et al. 2008) that included 46 subjects with experienced, stimulant-preferring drug abuse history, examined the abuse potential of atomoxetine (Fig. 2). Subjects received double-blind, single doses of eight test drugs (placebo, $90 \mathrm{mg}$ methylphenidate, $60 \mathrm{mg}$ of the stimulant phentermine, 100 and $200 \mathrm{mg}$ desipramine, and 45 , 90, and $180 \mathrm{mg}$ atomoxetine) using a balanced Latin square design. The Drug Rating Questionnaire-Subject (DRQS) and subscales of the ARCI data were collected for $24 \mathrm{~h}$ after each dose. Six-hour maximum scores were compared using analysis of variance. Methylphenidate and phentermine produced stimulant-like effects and euphoria, with significant scores on the DRQS "liking" subscale and the morphine-benzedrine, amphetamine, and benzedrine ARCI subscales. None of the doses of atomoxetine or desipramine produced stimulant-like effects or euphoria as measured by these scales. In this population of stimulant-preferring drug abusers, atomoxetine at doses up to $180 \mathrm{mg}$ was not a euphoriant and did not produce stimulant-like subjective effects. Overall, the human laboratory studies strongly suggest a low abuse potential of atomoxetine.

\section{Other human studies}

To date, there are no studies evaluating the abuse potential of atomoxetine in patients with ADHD. However, atomoxetine treatment in a double-blind placebo-controlled trial in adult patients with ADHD and comorbid ethanol abuse/depenendence, resulted in improvement in ADHD symptoms (Wilens et al. 2008b), which was significantly correlated with reduced alcohol cravings (Wilens et al. 2011). Further, the reduction in ADHD symptoms in the atomoxetine-treated group was not altered despite relapse to alcohol abuse. A post hoc analysis revealed that the cumulative heavy drinking days did not decrease until after
ADHD symptoms improved and the adverse event profile was not suggestive of abuse potential for atomoxetine (Wilens et al. 2011).

Another approach is to study types of symptoms (e.g., dysphoria or depression, insomnia, irritability, frustration or anger, anxiety, and restlessness) immediately following discontinuation as to whether they suggest a drug withdrawal syndrome. Wernicke et al. (2004) evaluated the effects of abrupt discontinuation of atomoxetine in four placebocontrolled trials in children and adults with ADHD. Two of those were identical studies in children involved 9 weeks double-blind treatment followed by abrupt discontinuation or 1 week of single-blind placebo treatment. The other two were identical studies in adults involved 9-10 weeks double-blind treatment followed by a 4-week double-blind discontinuation phase where those on placebo comtinued on placebo and those on atomoxetine were randomized to either abrupt or tapered discontinuation. Atomoxetine was not associated with an acute discontinuation syndrome and hence, may be discontinued without risk of discontinuation-emergent adverse effects (Wernicke et al. 2004; http://pi.lilly.com/us/ strattera-pi.pdf). The lack of discontinuation syndrome provides further supporting evidence for the low-abuse potential of atomoxetine.

\section{Conclusions}

The abuse potential evaluation for atomoxetine reviewed here was comprehensive and involved preclinical and clinical assessments including neuropharmaceutical characterization, receptor binding studies, animal behavioral studies (reinforcing effects, discriminative effects, physical dependence, and tolerance), and human pharmacology studies (subjective effects, toxicity and performance impairement, tolerance and physical dependence). Atomoxetine was not placed under CSA, which includes the US FDA's eightfactor analysis of abuse potential for determination of control and scheduling of drugs prior to marketing. Atomoxetine was approved for the treatment of patients with ADHD as an uncontrolled and unscheduled medication in contrast to methylphenidate and amphetamine, which are placed under CSA and approved as schedule II (high physical or psychological dependence potential) drugs based on the eight-factor analysis.

Data from the in vitro and in vivo preclinical studies suggest that unlike stimulants (e.g., methylphenidate, amphetamines), atomoxetine does not have appreciable abuse potential. Further, atomoxetine was not associated with discontinuation-emergent adverse events in patients with ADHD in clinical trials that are suggestive of physical dependency.

Human abuse potential studies in atomoxetine were conducted in subjects with histories of substance abuse, which 
is a standard procedure in the field. There is a growing body of literature examining medication diversion and misuse (Upadhyaya 2007; Wilens et al. 2008a). Evidence from those studies as well as from the postmarketing surveillance over the past 10 years has not indicated that atomoxetine is misused or diverted (Upadhyaya 2007; Wilens et al. 2008a).

Collectively, the broad experimental research summarized in this review supports that atomoxetine lacks abuse potential. As such, atomoxetine offers an alternative and efficacious nonstimulant treatment option for patients with ADHD.

Implications for future abuse potential research

It is evident that a comprehensive approach is needed for the evaluation of abuse potential of a psychoactive drug and that the results of a single study cannot be relied on to adequately characterize the potential for abuse. The eight-factor analysis conducted by the FDA seems like a reasonable first step that was able to predict lack of abuse potential with atomoxetine. Given that significant resources are required to conduct a program addressing the eight factors, more specific guidance, e.g., conditions under which such a program is needed, the type of required studies, animal models needed to be examined, types of comparators needed in human studies would be helpful.

Conflict of interest Drs. Upadhyaya, Desaiah, K. Schuh, Clarke, Durell, Trzepacz, Calligaro, Nisenbaum, Emmerson, and Allen are employees and shareholders of Eli Lilly and Company. Dr. L. Schuh is a former employee of Eli Lilly and Company and is currently affiliated with the St. Vincent Carmel Hospital, Carmel, IN. Mr. Bymaster and Dr. Kallman retired from Eli Lilly and Company and are currently affiliated with Indiana University, Indianapolis, IN, and Covance Laboratories, Greenfield, IN, respectively. Dr. Bickel received funding from Eli Lilly and Company in the past for his research. Frank P. Bymaster was an employee of the Eli Lilly and Company when the manuscript was initially written.

Financial support This research was funded by Eli Lilly and Company.

Open Access This article is distributed under the terms of the Creative Commons Attribution License which permits any use, distribution, and reproduction in any medium, provided the original author(s) and the source are credited.

\section{References}

American Psychiatric Association (2000) Diagnostic and statistical manual of mental disorders, 4th edn. American Psychiatric Association, Washington, DC

Barkley RA, Fischer M, Smallish L, Fletcher K (2002) The persistence of attention-deficit/hyperactivity disorder into young adulthood as a function of reporting source and definition of disorder. J Abnorm Psychol 111:279-289

Bergman J, Madras BK, Johnson SE, Spealman RD (1989) Effects of cocaine and related drugs in nonhuman primates. III Selfadministration by squirrel monkeys. J Pharmacol Exp Ther 251:150-155

Bergman J, France CP, Holtzman SG, Katz JL, Koek W, Stephens DN (2000) Agonist efficacy, drug dependence, and medications development: preclinical evaluation of opioid, dopaminergic, and GABAA-ergic ligands. Psychopharmacology (Berlin) 153:67-84

Berman SM, Kuczenski R, McCracken JT, London ED (2009) Potential adverse effects of amphetamine treatment on brain and behavior: a review. Mol Psychiatry 14:123-142

Biederman J, Wilens T, Mick E, Faraone SV, Weber W, Curtis S, Thornell A, Pfister K, Jetton JG, Soriano J (1997) Is ADHD a risk factor for psychoactive substance use disorders? Findings from a four-year prospective follow-up study. J Am Acad Child Adolesc Psychiatry 36:21-29

Bredeloux P, Dubuc I, Costentin J (2007) Comparisons between bupropion and dexamphetamine in a range of in vivo tests exploring dopaminergic transmission. Br J Pharmacol 150:711-719

Bymaster FP, Katner JS, Nelson DL, Hemrick-Luecke SK, Threlkeld PG, Heiligenstein JH, Morin SM, Gehlert DR, Perry KW (2002) Atomoxetine increases extracellular levels of norepinephrine and dopamine in prefrontal cortex of rat: a potential mechanism for efficacy in attention deficit/hyperactivity disorder. Neuropsychopharmacology 27:699-711

Chase TD, Carrey N, Brown RE, Wilkinson M (2005) Methylphenidate regulates c-fos and fosB expression in multiple regions of the immature rat brain. Brain Res Dev Brain Res 156:1-12

Cheetham SC, Viggers JA, Butler SA, Prow MR, Heal DJ (1996) [3H] nisoxetine - a radioligand for noradrenaline reuptake sites: correlation with inhibition of [3H]noradrenaline uptake and effect of DSP-4 lesioning and antidepressant treatments. Neuropharmacology 35:63-70

Darvesh AS, Carroll RT, Geldenhuys WJ, Gudelsky GA, Klein J, Meshul CK, Van der Schyf CJ (2011) In vivo brain microdialysis: advances in neuropsychopharmacology and drug discovery. Expert Opin Drug Discov 6:109-127

Di Chiara G, Tanda GL, Frau R, Carboni E (1992) Heterologous monoamine reuptake: lack of transmitter specificity of neuronspecific carriers. Neurochem Int 20(Suppl):231S-235S

Dragunow M, Faull R (1989) The use of c-fos as a metabolic marker in neuronal pathway tracing. J Neurosci Methods 29:261-265

Faraone SV, Sergeant J, Gillberg C, Biederman J (2003) The worldwide prevalence of ADHD: is it an American condition? World Psychiatry 2:104-113

Garland EJ (1998) Intranasal abuse of prescribed methylphenidate. J Am Acad Child Adolesc Psychiatry 37:1242-1243

Garnock-Jones KP, Keating GM (2010) Spotlight on atomoxetine in attention-deficit hyperactivity disorder in children and adolescents. CNS Drugs 24:85-88

Gasior M, Bergman J, Kallman MJ, Paronis CA (2005) Evaluation of the reinforcing effects of monoamine reuptake inhibitors under a concurrent schedule of food and i.v. drug delivery in rhesus monkeys. Neuropsychopharmacology 30:758-764

Gatley SJ, Pan D, Chen R, Chaturvedi G, Ding YS (1996) Affinities of methylphenidate derivatives for dopamine, norepinephrine and serotonin transporters. Life Sci 58:231-239

Graham D, Langer SZ (1992) Advances in sodium-ion coupled biogenic amine transporters. Life Sci 51:631-645

Greydanus DE, Pratt HD, Patel DR (2007) Attention deficit hyperactivity disorder across the lifespan: the child, adolescent, and adult. Dis Mon 53:70-131

Hechtman L (2000) Assessment and diagnosis of attention-deficit/ hyperactivity disorder. Child Adolesc Psychiatr Clin N Am 9:481-498 
Heil SH, Holmes HW, Bickel WK, Higgins ST, Badger GJ, Laws HF, Faries DE (2002) Comparison of the subjective, physiological, and psychomotor effects of atomoxetine and methylphenidate in light drug users. Drug Alcohol Depend 67:149-156

Jasinski DR, Faries DE, Moore RJ, Schuh LM, Allen AJ (2008) Abuse potential assessment of atomoxetine in a drug-abusing population. Drug Alcohol Depend 95:140-146

Johanson CE, Barrett JE (1993) The discriminative stimulus effects of cocaine in pigeons. J Pharmacol Exp Ther 267:1-8

Johanson CE, Schuster CR (1975) A choice procedure for drug reinforcers: cocaine and methylphenidate in the rhesus monkey. $\mathrm{J}$ Pharmacol Exp Ther 193:676-688

Johnston LD, O'Malley PM, Bachman JG, Schulenberg JE (2008) Monitoring the future national survey results on drug use, 19752007. Volume II: college students and adults ages 19-45. National Institute on Drug Abuse, US Department of Health and Human Services, Bethesda, MD

Johnston LD, O’Malley PM, Bachman JG, Schulenberg JE (2009) Monitoring the Future national survey results on drug use, 1975-2008. Volume II: college students and adults ages 19-50 (NIH Publication No. 09-7403). National Institute on Drug Abuse, US Department of Health and Human Services, Bethesda, MD

Johnston LD, O'Malley PM, Bachman JG, Schulenberg JE (2011) Monitoring the Future national survey results on drug use, 1975-2010. Volume II: college students and adults ages 19-50. Institute for Social Research, The University of Michigan, Ann Arbor

Johnston LD, O'Malley PM, Bachman JG, Schulenberg JE (2012) Monitoring the Future national results on adolescent drug use: overview of key findings, 2011. Institute for Social Research, The University of Michigan, Ann Arbor

Jones S, Kornblum JL, Kauer JA (2000) Amphetamine blocks longterm synaptic depression in the ventral tegmental area. J Neurosci 20:5575-5580

Kahlig KM, Binda F, Khoshbouei H, Blakely RD, McMahon DG, Javitch JA, Galli A (2005) Amphetamine induces dopamine efflux through a dopamine transporter channel. Proc Natl Acad Sci U S A 102:3495-3500

Kessler RC, Adler L, Barkley R, Biederman J, Conners CK, Demler O, Faraone SV, Greenhill LL, Howes MJ, Secnik K, Spencer T, Ustun TB, Walters EE, Zaslavsky AM (2006) The prevalence and correlates of adult ADHD in the United States: results from the National Comorbidity Survey Replication. Am J Psychiatry 163:716-723

Kleven MS, Anthony EW, Woolverton WL (1990) Pharmacological characterization of the discriminative stimulus effects of cocaine in rhesus monkeys. J Pharmacol Exp Ther 254:312-317

Koda K, Ago Y, Cong Y, Kita Y, Takuma K, Matsuda T (2010) Effects of acute and chronic administration of atomoxetine and methylphenidate on extracellular levels of noradrenaline, dopamine and serotonin in the prefrontal cortex and striatum of mice. J Neurochem 114:259-270

Kollins SH (2007) Abuse potential of medications used to treat attention deficit/hyperactivity disorder (ADHD). Am J Addict 16(suppl 1):35-42

Koob GF (1992) Neural mechanisms of drug reinforcement. Ann N Y Acad Sci 654:171-191

Kuczenski R, Segal DS (1997) Effects of methylphenidate on extracellular dopamine, serotonin, and norepinephrine: comparison with amphetamine. J Neurochem 68:2032-2037

Kuczenski R, Segal DS (1999) Dynamic changes in sensitivity occur during the acute response to cocaine and methylphenidate. Psychopharmacology (Berlin) 147:96-103

Lile JA, Stoops WW, Durell TM, Glaser PE, Rush CR (2006) Discriminative-stimulus, self-reported, performance, and cardiovascular effects of atomoxetine in methylphenidate-trained humans. Exp Clin Psychopharmacol 14:136-147
Lin JS, Hou Y, Jouvet M (1996) Potential brain neuronal targets for amphetamine-, methylphenidate-, and modafinil-induced wakefulness, evidenced by c-fos immunocytochemistry in the cat. Proc Natl Acad Sci U S A 93:14128-14133

Massello W III, Carpenter DA (1999) A fatality due to the intranasal abuse of methylphenidate (Ritalin). J Forensic Sci 44:220-221

Mazei MS, Pluto CP, Kirkbride B, Pehek EA (2002) Effects of catecholamine uptakeblockers in the caudate-putamen and subregions of the medial prefrontal cortex of the rat. Brain Res 936:58-67

Michelson D, Allen AJ, Busner J, Casat C, Dunn D, Kratochvil C, Newcorn J, Sallee FR, Sangal RB, Saylor K, West S, Kelsey D, Wernicke J, Trapp NJ, Harder D (2002) Once-daily atomoxetine treatment for children and adolescents with attention deficit hyperactivity disorder: a randomized, placebo-controlled study. Am J Psychiatry 159:1896-1901

Michelson D, Adler L, Spencer T, Reimherr FW, West SA, Allen AJ, Kelsey D, Wernicke J, Dietrich A, Milton D (2003) Atomoxetine in adults with ADHD: two randomized, placebo-controlled studies. Biol Psychiatry 53:112-120

Molina BS, Pelham WE Jr (2003) Childhood predictors of adolescent substance use in a longitudinal study of children with ADHD. J Abnorm Psychol 112:497-507

Morgan JI, Curran T (1990) Inducible proto-oncogenes of the nervous system: their contribution to transcription factors and neuroplasticity. Prog Brain Res 86:287-294

Murnane KS, Howell LL (2011) Neuroimaging and drug taking in primates. Psychopharmacology 216:153-171

Nicholson KL, Balster RL, Golembiowska K, Kowalska M, Tizzano JP, Skolnick P, Basile AS (2009) Preclinical evaluation of the abuse potential of the analgesic bicifadine. J Pharmacol Exp Ther 330:236-248

Novak SP, Kroutil LA, Williams RL, Van Brunt DL (2007) The nonmedical use of prescription ADHD medications: results from a national Internet panel. Subst Abuse Treat Prev Policy 2:32

Parran TV Jr, Jasinski DR (1991) Intravenous methylphenidate abuse. Prototype for prescription drug abuse. Arch Intern Med 151:781-783

Partilla JS, Dempsey AG, Nagpal AS, Blough BE, Baumann MH, Rothman RB (2006) Interaction of amphetamines and related compounds at the vesicular monoamine transporter. J Pharmacol Exp Ther 319:237-246

Paterson NE, Fedolak A, Olivier B, Hanania T, Ghavami A, Caldarone B (2010) Psychostimulant-like discriminative stimulus and locomotor sensitization properties of the wake-promoting agent modafinil in rodents. Pharmacol Biochem Behav 95:449-456

Pontieri FE, Tanda G, Di Chiara G (1995) Intravenous cocaine, morphine, and amphetamine preferentially increase extracellular dopamine in the "shell" as compared with the "core" of the rat nucleus accumbens. Proc Natl Acad Sci U S A 92:12304-12348

Pristupa ZB, Wilson JM, Hoffman BJ, Kish SJ, Niznik HB (1994) Pharmacological heterogeneity of the cloned and native human dopamine transporter: disassociation of [3H]WIN 35,428 and [3H]GBR 12,935 binding. Mol Pharmacol 45:125-135

Ritz MC, Lamb RJ, Goldberg SR, Kuhar MJ (1987) Cocaine receptors on dopamine transporters are related to self-administration of cocaine. Science 237:1219-1223

Robertson GS, Matsumura H, Fibiger HC (1994) Induction patterns of Fos-like immunoreactivity in the forebrain as predictors of atypical antipsychotic activity. J Pharmacol Exp Ther 271:1058-1066

Rowlett JK, Platt DM, Yao WD, Spealman RD (2007) Modulation of heroin and cocaine self-administration by dopamine D1- and D2like receptor agonists in rhesus monkeys. J Pharmacol Exp Ther 321:1135-1143

Rush CR, Essman WD, Simpson CA, Baker RW (2001) Reinforcing and subject-rated effects of methylphenidate and d-amphetamine in nondrug-abusing humans. J Clin Psychopharmacol 21:273-286 
Sandoval V, Riddle EL, Hanson GR, Fleckenstein AE (2002) Methylphenidate redistributes vesicular monoamine transporter-2: role of dopamine receptors. J Neurosci 22:8705-8710

Sasaki JE, Tatham TA, Barrett JE (1995) The discriminative stimulus effects of methamphetamine in pigeons. Psychopharmacology (Berlin) 120:303-310

Shekim WO, Asarnow RF, Hess E, Zaucha K, Wheeler N (1990) A clinical and demographic profile of a sample of adults with attention deficit hyperactivity disorder, residual state. Compr Psychiatry 31:416-425

Simpson D, Plosker GL (2004) Atomoxetine: a review of its use in adults with attention deficit hyperactivity disorder. Drugs 64:205-222

Smoot LC, Boothby LA, Gillett RC (2007) Clinical assessment and treatment of ADHD in children. Int J Clin Pract 61:1730-1738

Spealman RD (1995) Noradrenergic involvement in the discriminative stimulus effects of cocaine in squirrel monkeys. J Pharmacol Exp Ther 275:53-62

Spencer T, Biederman J, Wilens T, Prince J, Hatch M, Jones J, Harding M, Faraone SV, Seidman L (1998) Effectiveness and tolerability of tomoxetine in adults with attention deficit hyperactivity disorder. Am J Psychiatry 155:693-695

Spencer T, Heiligenstein JH, Biederman J, Faries DE, Kratochvil CJ, Conners CK, Potter WZ (2002) Results from 2 proof-ofconcept, placebo-controlled studies of atomoxetine in children with attention-deficit/hyperactivity disorder. J Clin Psychiatry 63:1140-1147

Substance Abuse and Mental Health Services Administration (2006) Results from the 2005 National Survey on Drug Use and Health: national findings. Office of Applied Studies, US Department of Health and Human Services, Rockville, MD

Substance Abuse and Mental Health Services Administration (2007) Drug Abuse Warning Network, 2005: national estimates of drugrelated emergency department visits. Office of Applied Studies, US Department of Health and Human Services, Rockville

Tatsumi M, Groshan K, Blakely RD, Richelson E (1997) Pharmacological profile of antidepressants and related compounds at human monoamine transporters. Eur J Pharmacol 340:249-258

Terry P, Witkin JM, Katz JL (1994) Pharmacological characterization of the novel discriminative stimulus effects of a low dose of cocaine. J Pharmacol Exp Ther 270:1041-1048

The National Center on Addiction and Substance Abuse at Columbia University (2007) Wasting the best and the brightest: substance abuse at America's colleges and universities. http://www.casacolumbia.org/ absolutenm/articlefiles/380-Wasting\%20the \%20Best $\% 20$ and $\%$ 20the\%20Brightest.pdf. Accessed 9 Dec 2009

Tidey JW, Bergman J (1998) Drug discrimination in methamphetaminetrained monkeys: agonist and antagonist effects of dopaminergic drugs. J Pharmacol Exp Ther 285:1163-1174

Upadhyaya HP (2007) Managing attention-deficit/hyperactivity disorder in the presence of substance use disorder. J Clin Psychiatry 68(Suppl 11):23-30

Upadhyaya HP, Rose K, Wang W, O'Rourke K, Sullivan B, Deas D, Brady KT (2005) Attention-deficit/hyperactivity disorder, medication treatment, and substance use patterns among adolescents and young adults. J Child Adolesc Psychopharmacol 15:799-809
Upadhyaya HP, Kroutil LA, Deas D, Durell TM, Van Brunt DL, Novak SP (2010) Stimulant formulation and motivation for nonmedical use of prescription attention-deficit/hyperactivity disorder medications in a college-aged population. Am J Addict 19:569-577

Volkow ND, Swanson JM (2003) Variables that affect the clinical use and abuse of methylphenidate in the treatment of ADHD. Am J Psychiatry 160:1909-1918

Volkow ND, Wang GJ, Fischman MW, Foltin RW, Fowler JS, Abum$\operatorname{rad}$ NN, Vitkun S, Logan J, Gatley SJ, Pappas N, Hitzemann R, Shea CE (1997) Relationship between subjective effects of cocaine and dopamine transporter occupancy. Nature 386:827-830

Volkow ND, Wang GJ, Fowler JS, Gatley SJ, Logan J, Ding YS, Hitzemann R, Pappas N (1998) Dopamine transporter occupancies in the human brain induced by therapeutic doses of oral methylphenidate. Am J Psychiatry 155:1325-1331

Volkow ND, Wang G, Fowler JS Logan J, Gerasimov M, Maynard L, Ding Y, Gatley SJ, Gifford A, Franceschi D (2001) Therapeutic doses of oral methylphenidate significantly increase extracellular dopamine in the human brain. J Neurosci 21:RC121

Wee S, Woolverton WL (2004) Evaluation of the reinforcing effects of atomoxetine in monkeys: comparison to methylphenidate and desipramine. Drug Alcohol Depend 75:271-276

Wernicke JF, Adler L, Spencer T, West SA, Allen AJ, Heiligenstein J, Milton D, Ruff D, Brown WJ, Kelsey D, Michelson D (2004) Changes in symptoms and adverse events after discontinuation of atomoxetine in children and adults with attention deficit/hyperactivity disorder: a prospective, placebo-controlled assessment. J Clin Psychopharmacol 24:30-35

Wilens TE, Biederman J, Mick E, Faraone SV, Spencer T (1997) Attention deficit hyperactivity disorder (ADHD) is associated with early onset substance use disorders. J Nerv Ment Dis 185:475-482

Wilens TE, Adler LA, Adams J, Sgambati S, Rotrosen J, Sawtelle R, Utzinger L, Fusillo S (2008a) Misuse and diversion of stimulants prescribed for ADHD: a systematic review of the literature. J Am Acad Child Adolesc Psychiatry 47:21-31

Wilens TE, Adler LA, Weiss MD, Michelson D, Ramsey JL, Moore RJ, Renard D, Brady KT, Trzepacz PT, Schuh LM, Ahrbecker LM, Levine LR, Atomoxetine ADHD/SUD Study Group (2008b) Atomoxetine treatment of adults with ADHD and comorbid alcohol use disorders. Drug Alcohol Depend 96:145-154

Wilens TE, Adler LA, Tanaka Y, Xiao F, D'Souza DN, Gutkin SW, Upadhyaya HP (2011) Correlates of alcohol use in adults with ADHD and comorbid alcohol use disorders: exploratory analysis of a placebocontrolled trial of atomoxetine. Curr Med Res Opin 27:2309-2320

Wilson MC, Hitomi M, Schuster CR (1971) Psychomotor stimulant self administration as a function of dosage per injection in the rhesus monkey. Psychopharmacologia 22:271-281

Yano M, Steiner H (2005) Topography of methylphenidate (ritalin)-induced gene regulation in the striatum: differential effects on c-fos, substance P and opioid peptides. Neuropsychopharmacology 30:901-915

Zhang L, Barrett JE (1991) Imipramine as a discriminative stimulus. J Pharmacol Exp Ther 259:1088-1093

Zhang SJ, Huguenard JR, Prince DA (1997) GABA $_{A}$ receptormediated $\mathrm{Cl}^{-}$currents in rat thalamic reticular and relay neurons. J Neurophysiol 78:2280-2286 